\title{
Tissue-Specific Developmental Regulation of the Messenger Ribonucleic Acids Encoding the Growth Hormone Receptor and the Growth Hormone Binding Protein in Rat Fetal and Postnatal Tissues
}

\author{
JAN L. WALKER, BILLIE M. MOATS-STAATS, ALAN D. STILES, AND LOUIS E. UNDERWOOD
}

Division of Pediatric Endocrinology [J.L.W., B.M.M.S., L.E.U.], and Division of Neonatology [A.D.S.], University of North Carolina at Chapel Hill, North Carolina 27599-7220

\begin{abstract}
Tissue responsiveness to growth hormone is likely to be regulated by local concentrations and availability of the membrane-bound growth hormone receptor (GHR) and perhaps by the actions of the soluble growth hormone binding protein (GHBP). To determine whether the developmental regulation of the GHR and GHBP might vary among tissues, we have measured the relative abundance of the 4.3-kb GHR and 1.3-kb GHBP mRNA in rat fetal and postnatal liver, kidney, lung, and ileum by Northern hybridization of polyadenylated $R N A$ with a ${ }^{32} \mathrm{P}$-labeled antisense riboprobe prepared from a rat GHR cDNA. The GHR and GHBP mRNA were both present in the four tissues studied at fetal age $19 \mathrm{~d}$ (E19). In postnatal liver, both transcripts increased in abundance 3- to 4-fold after $14 \mathrm{~d}$ to mature levels at $42 \mathrm{~d}(p=0.0001)$. Similar changes were seen in postnatal kidney for GHR mRNA abundance; however, GHBP mRNA abundance increased only 2- to 3-fold to mature levels by $28 \mathrm{~d}$ (kidney GHR versus GHBP mRNA profile, $p=0.0001$ ). In lung, a 2fold linear increase in GHR mRNA abundance was observed ( $p=0.0019$ ), but the GHBP mRNA did not change (GHR versus GHBP mRNA profile, $p=0.0006$ ). Both transcripts decreased in abundance by 2 - to 3 -fold from E19 to $42 \mathrm{~d}$ in ileum $(p<0.05)$. The abundance of both transcripts was three to 10 times greater in 60-d liver than in the other three tissues at $60 \mathrm{~d}$. The variation in abundance and in the developmental profiles of the GHR and GHBP mRNA observed in these fetal and postnatal tissues suggests that the GHR and GHBP could mediate differences within and between tissues in the responsiveness to growth hormone. The differential regulation of the two transcripts evident in kidney and lung supports the emerging evidence that the GHBP may have a function distinct from that of the GHR. (Pediatr Res 31: 335-339, 1992)
\end{abstract}

\section{Abbreviations}

GH, growth hormone

GHR, growth hormone receptor

GHBP, growth hormone binding protein

poly $\mathrm{A}^{+}$, polyadenylated RNA

Received September 17, 1991; accepted December 4, 1991.

Correspondence: Louis E. Underwood, M.D., Department of Pediatric Endocrinology, 509 Burnett-Womack, \#CB 7220, The University of North Carolina at Chapel Hill, Chapel Hill, NC 27599-7220.

Supported by NIH Grants HL38902 and HD26871.
Receptors for $\mathrm{GH}$ exist in both membrane-bound and soluble forms (1). The cDNA encoding the membrane-bound GHR in rats (2) has been shown in cell transfection studies to mediate the effects of $\mathrm{GH}$ on protein synthesis (3). The soluble GHR, the GHBP, appears to be an alternatively spliced product of the GHR gene in rats (4) that is composed of the extracellular domain of the GHR but that has a unique 17-amino acid hydrophilic tail instead of the transmembrane and intracellular domains of the receptor. The function of the GHBP has not been defined; however, in vitro studies indicate that it may compete with the GHR for $\mathrm{GH}$ binding $(5,6)$. As a potential competitor for ligand binding, the GHBP may have a role distinct from that of the GHR in modulating tissue responses to circulating $\mathrm{GH}$.

The responsiveness of tissues to $\mathrm{GH}$ is likely to vary according to the concentration and availability of GHR. Sites that bind radiolabeled $\mathrm{GH}$ are most abundant in liver, and only low levels of $\mathrm{GH}$ binding have been found in other tissues of mature animals (7). The mRNA encoding the GHR, however, is found in most adult tissues in the rat $(2,8)$. The increased sensitivity offered by techniques that measure mRNA abundance may therefore allow closer scrutiny of GHR regulation and function, provided that concentrations of GHR mRNA and translated protein are found to be tightly linked.

Mathews et al. (2) showed that mRNA hybridizing to a GHR probe increase in abundance in liver, kidney, muscle, and heart with postnatal age. The solution hybridization technique used, however, did not distinguish between the 4.3-kb mRNA encoding the GHR and the 1.3-kb mRNA encoding the GHBP. These distinct mRNA can be quantified by Northern hybridization with a CDNA probe homologous with the extracellular domain of the GHR. Using this technique, we have studied the expression of the GHR and GHBP mRNA in rat fetal and postnatal tissues. Our aims were 1 ) to determine whether there are differences between tissues in developmental regulation, which might indicate variations in tissue responsiveness to $\mathrm{GH}$, and 2) to determine whether the GHR and GHBP mRNA are differentially regulated, which would suggest that they might have different functions.

\section{MATERIALS AND METHODS}

Animals. Female Sprague-Dawley rats were housed under standard laboratory conditions with free access to water and food. The animals were killed by decapitation at $7,14,28,42$, and $60 \mathrm{~d}$ of age, and the liver, kidneys, ileum, and lungs were dissected, frozen in liquid nitrogen, and stored at $-70^{\circ} \mathrm{C}$ for later RNA extraction. Pregnant females were killed by ether anesthesia 
19 d postcoitus (E19). The E19 fetuses were killed by decapitation, and liver, lungs, kidneys, and whole intestines were collected and stored at $-70^{\circ} \mathrm{C}$. The protocol was approved by the Institutional Animal Care and Use Committee of the University of North Carolina at Chapel Hill.

Poly $A^{+}$preparation and analysis. Tissue from several rats at each time point was pooled, and 0.5 -g aliquots were used to prepare total RNA by homogenization in $4 \mathrm{M}$ guanidine thiocyanate followed by centrifugation over a $5.7 \mathrm{M} \mathrm{CsCl}$ cushion (9). The total RNA pellets were further enriched for poly $\mathrm{A}^{+}$by oligo dT affinity chromatography (10).

Aliquots of poly $\mathrm{A}^{+}$were denatured in glyoxal and DMSO (11) and size-fractionated on $1 \%$ agarose gels in $10 \mathrm{mM}$ sodium phosphate. The gels were ethidium bromide-stained and photographed to document the uniformity of loading. The RNA was then transferred to Genescreen nylon membranes (New England Nuclear, Cambridge, MA) by capillary action (12), after which the membranes were UV cross-linked for $2 \mathrm{~min}$ and baked for 2 $h$ at $80^{\circ} \mathrm{C}$.

Probes and labeling. A ${ }^{32} \mathrm{P}$-labeled antisense riboprobe specific for both the GHR and the GHBP was generated by in vitro transcription from a 951-bp Bg/II fragment of the cDNA encoding the GHR cloned into the vector pT7T3 (generous gift of Dr. Lawrence Mathews) (2) using ${ }^{32}$ P-UTP (Amersham Corp., Arlington Heights, IL) and T7 RNA polymerase (Stratagene, La Jolla, CA) (13). To confirm that patterns of hybridization seen using the GHR riboprobe were specific for the GHR and GHBP mRNAs, duplicate blots of female liver poly $\mathrm{A}^{+}(\mathrm{E} 19$ to $60 \mathrm{~d})$ were hybridized with ${ }^{32} \mathrm{P}$-end labeled oligonucleotide probes (14) specific for either the intracellular domain of the GHR [bases 1568 to 1606 (2)] or the 3' sequence unique to the GHBP [bases 798 to $834(4)]$

A ubiquitin cDNA was ${ }^{32} \mathrm{P}$-labeled by random priming (15) and used in addition to ethidium bromide staining of gels to verify uniformity in loading.

Hybridization conditions. Hybridization with the ${ }^{32} \mathrm{P}$-labeled GHR riboprobe $\left(2 \times 10^{6} \mathrm{cpm} / \mathrm{mL}\right.$ hybridization buffer $)$ was performed overnight at $65^{\circ} \mathrm{C}$ in a solution of $50 \%$ formamide, $0.8 \mathrm{M} \mathrm{NaCl}, 2.5 \times$ Denhardt's, $0.1 \%$ SDS, $0.05 \mathrm{M}$ sodium phosphate, $\mathrm{pH} 6.8,0.5 \mathrm{mM}$ EDTA, and $400 \mu \mathrm{g} / \mathrm{mL}$ denatured salmon testes DNA. The blots were washed twice in a solution of $0.1 \% \mathrm{SDS}, 0.05 \mathrm{M} \mathrm{NaCl}, 0.1 \mathrm{mM}$ EDTA, and $0.02 \mathrm{M}$ sodium phosphate for $30 \mathrm{~min}$ each time at 70 and $75^{\circ} \mathrm{C}$ and subjected to autoradiography at $-70^{\circ} \mathrm{C}$. Duplicate blots of female liver poly $\mathrm{A}^{+}$were hybridized with the GHR and GHBP oligomers overnight at $42^{\circ} \mathrm{C}$ in $30 \%$ instead of $50 \%$ formamide and the hybridization solution detailed above, followed by two $30-\mathrm{min}$ washes at $50^{\circ} \mathrm{C}$ in $2 \times \mathrm{SSC}, 0.1 \%$ SDS. Rehybridization of blots with the ubiquitin CDNA was performed as previously described (16). For autoradiography, the blots were exposed to Kodak XAR x-ray film at $-70^{\circ} \mathrm{C}$ with intensifying screens. The abundance of the mRNA encoding the GHR and GHBP was quantified by densitometric scanning of the autoradiographs using an LKB ultrascan XL laser densitometer (LKB Instruments, Piscataway, NJ).

Analyses of results. Densitometric analysis of the autoradiographs of Northern blots reprobed with the ubiquitin cDNA and of the negatives from ethidium bromide-stained gels revealed no significant variation in the amount of mRNA loaded for liver, lung, and intestine/ileum. Therefore, the GHR and GHBP data were not modified. Kidney mRNA derived from two separate groups of rats at each time point (four blots) showed a decrease in ubiquitin mRNA abundance with increasing age. Because this was observed in both groups of rats and did not bias the GHR/ GHBP results, we also used the kidney GHR and GHBP densitometric data without correction.

For statistical analysis, the densitometric data were log transformed to decrease the variation between autoradiographs due to exposure time. The transformed data were subjected to a oneway repeated measures analysis of variance (SAS Institute, Cary,
NC) to determine whether GHR and GHBP mRNA abundance changed with age, to calculate and plot the curves of best fit (developmental profiles), and to determine whether there were significant differences between the developmental profiles for the GHR and the GHBP within each tissue. Only Northern blots with complete sets of time points were used. The fetal samples were not present on all blots and were therefore excluded from statistical analysis.

To determine the relative GHR and GHBP mRNA abundance in each tissue at different ages, the abundance observed in the tissue from 60-d animals was used as a control for the earlier time points within each Northern blot. Using all the Northern blots for a given tissue, the mean \pm SD \% 60-d GHR or GHBP mRNA abundance was calculated for E19 through d 42. Poly $\mathrm{A}^{+}$prepared from a single pool of livers from $60-\mathrm{d}$ animals was included in 5- or 10- $\mu$ g aliquots on each of the Northern blots of tissues other than liver and was used as a control for the relative abundance of the GHR and GHBP mRNA in 60-d kidney, lung, and ileum.

\section{RESULTS}

The developmental regulation of the GHR and GHBP mRNA transcripts varied according to the tissue, with significant changes for both transcripts occurring with age in liver, kidney, and ileum and for the GHR in lung (Fig. 1, Table 1). Both transcripts were present in each of the four tissues studied at $19 \mathrm{~d}$ gestation (Fig. 2), but differences were observed between tissues in the relative abundance of the mRNA encoding the GHR and GHBP in fetal tissues as compared with the postnatal time points (Table 1).

GHR mRNA abundance in liver was low at E19 $(4.2 \pm 0.1 \%$ mean \pm SD of 60 -d abundance) and increased postnatally, the most dramatic increase occurring between 14 and $42 \mathrm{~d}$. A similar profile was evident for the GHBP mRNA from liver (Fig. 1). Hybridization of the duplicate blots of female liver poly $\mathrm{A}^{+}$with the GHR- or GHBP-specific oligonucleotide probes confirmed that the 4.3-kb and 1.3-kb mRNA bands found on hybridization with the GHR riboprobe were specific for the GHR and the GHBP, respectively. The developmental profile of each mRNA species was also confirmed (Table 1).

There was a decrease from prenatal to postnatal mRNA abundance for the GHR in kidney (one blot with E19, 55\%; four blots with $7 \mathrm{~d}, 13 \pm 15 \%$; Table 1), but the postnatal profile resembled that of liver. By comparison, there was an earlier, more modest increase in mRNA for the GHBP in kidney $(7 \mathrm{~d}$, $44 \pm 13 \% ; 28 \mathrm{~d}, 121 \pm 73 \%$; GHBP versus GHR, $p=0.0001$ Table 1, Fig. 1).

The developmental profiles of the two transcripts also differed in lung, with no change in GHBP mRNA with age, but an initial decrease in GHR mRNA abundance from E19 to d 7 followed by a modest linear increase to d 60 (GHBP versus GHR, $p=$ 0.0016; Table 1, Fig. 1).

The developmental profiles for GHR and GHBP mRNA abundance in ileum were similar to one another but markedly different from the other three tissues in that the initial decrease from E19 to $\mathrm{d} 7$ was followed by a subsequent decrease to $\mathrm{d} 42$ (GHR, E19: $277 \pm 94 \%$; 42 d: $77 \pm 32 \%$; Table 1, Fig. 1).

The abundance of both transcripts in liver at $60 \mathrm{~d}$ was three to 10 times that found in 60-d kidney, lung, and ileum (Table 2).

\section{DISCUSSION}

The results show that GHR and GHBP transcripts are present in fetal tissues, that the developmental profiles for GHR and GHBP mRNA abundance differ among tissues, and that the two transcripts can be differentially regulated. The GHR and GHBP mRNA in mature rats were most abundant in liver, as has been reported previously $(2,8)$, and the increases in abundance of the GHR mRNA from d 7 to $\mathrm{d} 60$ in liver and kidney were similar 
A. GHR and GHBP mRNA Abundance
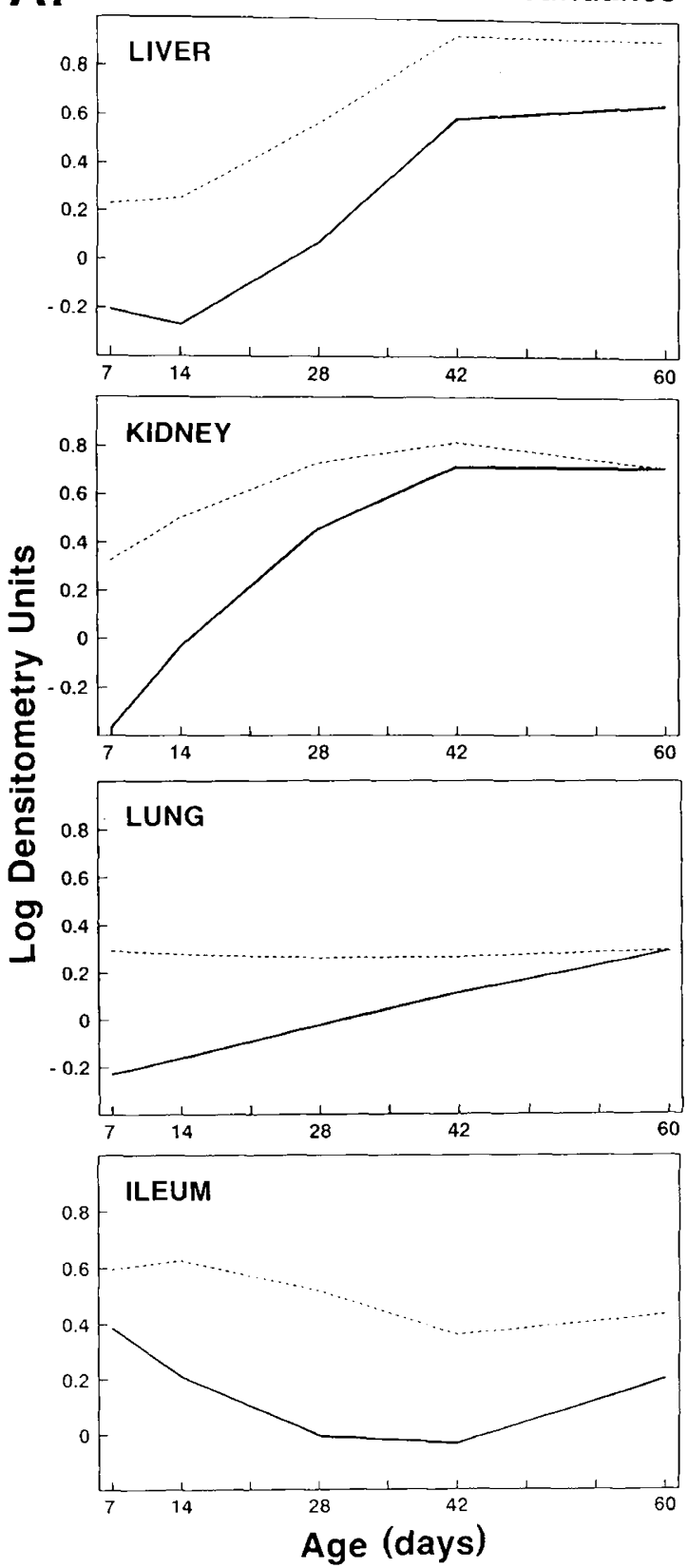

B.
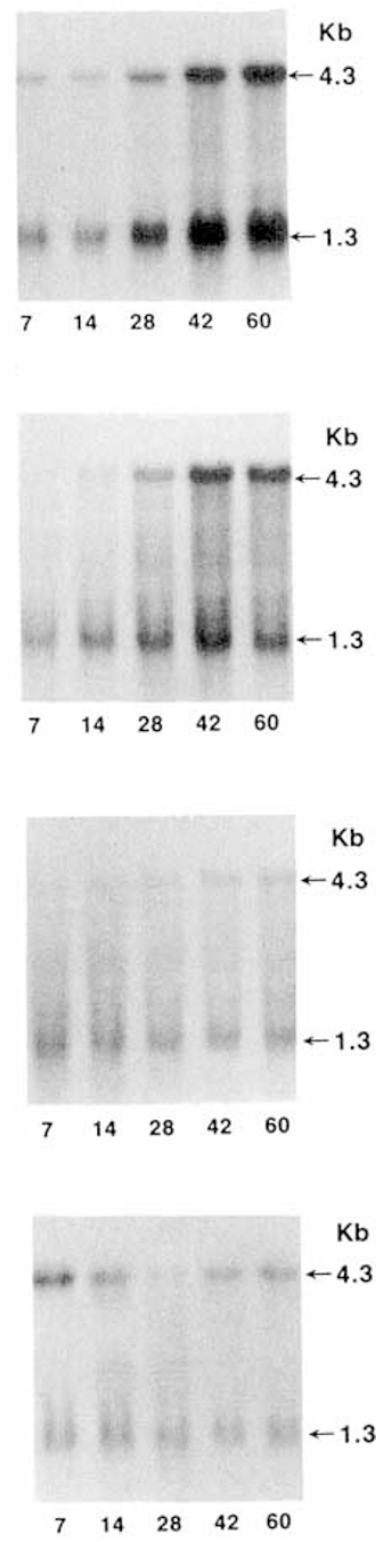

Age (days)

Fig. 1. A, The developmental profiles for GHR (-) and GHBP (---) mRNA abundance for postnatal rat liver, kidney, lung, and ileum. $B$, The corresponding autoradiographs of representative Northern blots of poly $\mathrm{A}^{+}$prepared from each tissue hybridized with a ${ }^{32} \mathrm{P}$-labeled antisense riboprobe to the rat GHR. Ten $\mu \mathrm{g}$ poly $\mathrm{A}^{+}$per lane were loaded for liver, and $20 \mu \mathrm{g}$ per lane were loaded for kidney, lung, and ileum. The numbers at the bottom of each panel in $A$ and $B$ correspond to the postnatal age in $\mathrm{d}$ of the rats from which the poly $\mathrm{A}^{+}$in each lane was obtained. The 4.3and 1.3-kb mRNA bands (arrows) correspond to GHR and the GHBP, respectively. Sizes were estimated by comparison with labeled denatured DNA molecular weight markers (not shown). A faint band $(\simeq 1.6 \mathrm{~kb})$ is also seen in RNA preparations of some tissues. The nature of this band is not clear. For statistical analysis, only Northern blots with complete sets of time points were used: three blots from one group of rats for liver and ileum, four blots from two groups for kidney, and six blots from three groups for lung. Significant increases in mRNA abundance with age were evident for the GHR and GHBP in liver and kidney $(p=0.0001)$ and for the GHR in lung $(p=0.0019)$. Significant decreases in GHR and GHBP mRNA abundance with increasing age were observed in ileum (GHR: $p=0.0434$; GHBP: $p=0.004)$. The developmental profiles for GHR versus GHBP mRNA abundance were significantly different in kidney $(p=0.0001)$ and lung $(p=0.0006)$.

to those found by use of solution hybridization (2). The increase of GHR mRNA in liver also paralleled the postnatal increase in $\mathrm{GH}$ binding sites on female liver membranes (17), suggesting a close relationship between GHR mRNA abundance and receptor protein concentrations. Similarly, the comparatively low GHR mRNA abundance observed in the other tissues is consistent with the low levels of $\mathrm{GH}$ binding reported for nonhepatic tissues (7). Inasmuch as the presence of functional $\mathrm{GH}$ receptors in most organs is strongly implied by the observation that $\mathrm{GH}$ stimulates local tissue production of IGF-I (18), molecular techniques for measuring GHR mRNA abundance may be a more sensitive way of studying GHR regulation than traditional binding methods.

The functional significance of our finding that the GHR and GHBP mRNA were present in all four fetal tissues studied is unclear. There is evidence to suggest that translation of the 
Table 1. Mean $\pm S D$ percentage of $60-d$ GHR and GHBP $m R N A$ abundance in liver, kidney, lung, and intestine/ileum from E19 through $d 42^{*}$

\begin{tabular}{|c|c|c|c|c|c|}
\hline & E19† & $7 d$ & $14 \mathrm{~d}$ & $28 \mathrm{~d}$ & $42 \mathrm{~d}$ \\
\hline \multicolumn{6}{|l|}{ Liver } \\
\hline GHR & $4.2 \pm 0.1$ & $17.6 \pm 16$ & $15.2 \pm 10.3$ & $25 \pm 7$ & $92 \pm 19$ \\
\hline (GHR)‡ & 4.4 & 11.4 & 18.3 & 33.8 & 76.3 \\
\hline GHBP & $4.4 \pm 0.1$ & $22 \pm 9$ & $22 \pm 10$ & $47 \pm 8$ & $100 \pm 6$ \\
\hline$(\mathrm{GHBP}) \ddagger$ & 9.2 & 29.8 & 27.5 & 65.3 & 121 \\
\hline \multicolumn{6}{|l|}{ Kidney } \\
\hline GHR & 55.3 & $13 \pm 15$ & $18 \pm 7$ & $67 \pm 43$ & $99 \pm 27$ \\
\hline GHBP & 39 & $44 \pm 13$ & $64 \pm 18$ & $121 \pm 73$ & $111 \pm 23$ \\
\hline \multicolumn{6}{|l|}{ Lung } \\
\hline GHR & $76 \pm 29$ & $40 \pm 32$ & $46 \pm 29$ & $55 \pm 33$ & $67 \pm 16$ \\
\hline GHBP & $87 \pm 20$ & $100 \pm 18$ & $99 \pm 18$ & $94 \pm 23$ & $96 \pm 28$ \\
\hline \multicolumn{6}{|l|}{ Ileum } \\
\hline GHR & $277 \pm 94 \S$ & $150 \pm 58$ & $138 \pm 3$ & $143 \pm 135$ & $77 \pm 32$ \\
\hline GHBP & $161 \pm 37 \S$ & $143 \pm 9$ & $164 \pm 4$ & $117 \pm 8$ & $88 \pm 13$ \\
\hline
\end{tabular}

* The Northern blots used represent poly A+ prepared from one group of rats for liver and ileum (three blots), two groups for kidney (four blots), and three groups for lung (six blots). Statistical analysis was not applied because the 60 -d animals, as arbitrary controls, could not be included.

† Gestational d 19 (E19) tissue appeared on one blot for kidney, two blots for liver and lung, and three blots for ileum

$\ddagger$ All blots were hybridized with the GHR riboprobe except for (GHR), which was hybridized with the GHR-specific oligomer, and (GHBP), which was hybridized with the GHBP-specific oligomer.

$\S$ Whole intestine rather than ileum was used.

\section{LIVER KIDNEY ILEUM LUNG}

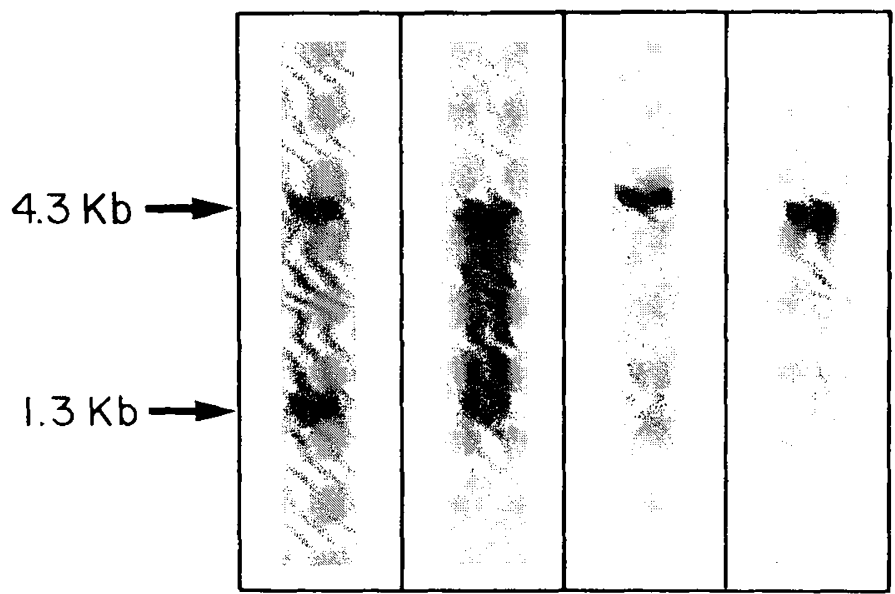

Fig. 2. Autoradiographs of representative Northern blots of poly $\mathrm{A}^{+}$ prepared from E19 fetal liver $(10 \mu \mathrm{g})$, kidney, intestine, and lung $(20 \mu \mathrm{g}$ each), hybridized with a ${ }^{32} \mathrm{P}$-labeled antisense riboprobe to the rat GHR. The 4.3- and 1.3-kb mRNA bands (arrows) correspond to the GHR and the GHBP, respectively.

Table 2. Mean $\pm S D G H R$ and GHBP $m R N A$ abundance in

kidney, lung, and ileum from 60-d rats expressed as percentage of GHR or GHBP $m R N A$ abundance in 60-d liver

\begin{tabular}{ccc}
\multicolumn{3}{c}{ of GHR or GHBP $m R N A$ abundance in $60-d$ liver } \\
\hline Kidney & $34.9 \pm 12.5$ & GHBP \\
Lung & $16 \pm 12$ & $30.4 \pm 12.2$ \\
Ileum & $12.7 \pm 3$ & $10.6 \pm 5$ \\
\hline
\end{tabular}

mRNA to their respective proteins probably occurs. Immunoreactive GHR protein has been reported on fetal rat cells as early as d 12 of gestation (19), and, in fetal rabbits, low levels of specific GHR binding have been found in the cytosols of several tissues, including liver, kidney, and lung, with relatively high levels in fetal serum (20). Furthermore, the differences between prenatal and postnatal abundance of GHR mRNA in the tissues that we studied parallel closely the profiles reported for IGF-I mRNA in the same tissues $(16,21)$, an observation that could be interpreted as an effect of GH on IGF-I production. On the other hand, although fetal growth and differentiation appear to be partly dependent on IGF-I and IGF-II (22), there is no evidence that $\mathrm{GH}$ is critical for these processes. The biologic relevance of $\mathrm{GH}$ receptors in fetal tissues therefore remains to be defined.

The linkage in postnatal tissues between GHR mRNA abundance, translated GHR protein concentrations, and tissue responsiveness to $\mathrm{GH}$ is supported by a number of observations. The tissue-specific developmental profiles for GHR mRNA abundance in liver, kidney, and ileum found in this study are strikingly similar to those reported for IGF-I mRNA in the same tissues $(16,21)$. GHR mRNA abundance is lower in lung than in the other tissues, and the developmental profile differs from that reported for the mRNA encoding IGF-I $(21,23)$. Consonant with this is the observation that lung growth is less GH-dependent than is growth of the other tissues. Lung growth is not affected by hypophysectomy at $6 \mathrm{~d}$ of age, whereas the growth of liver, kidney, and small intestine is significantly attenuated (24). Similarly, the growth response of lung in 7-wk-old hypophysectomized rats treated with GH was less than that observed in kidney or liver (18).

With the exception of the lung, the variation between tissues in the developmental profiles for GHR mRNA is also consistent with the known functions of GH during development. In liver, GH stimulates protein synthesis, induces enzymes, and modulates carbohydrate and lipid metabolism (25). In kidney, GH and IGF-I increase glomerular filtration rate, renal plasma flow, phosphate transport, and gluconeogenesis (26). The increases with age in liver and kidney GHR mRNA abundance are therefore consistent with the increasing metabolic demands of maturing animals. There is evidence that the growth of the neonatal small intestine and the maturation of its enzyme systems are partly GH dependent, and that an intact pituitary is critical for weaning and the acquisition of the ability to digest solid food (27). These observations are consistent with our finding that GHR and GHBP mRNA abundance is high in fetal and neonatal intestine relative to values later in life.

Because the 1.3-kb mRNA encoding the GHBP is a distinct gene product in rats (4), differential regulation of the GHR and GHBP mRNA is possible. We recently observed that hypophysectomized rats continuously infused with $\mathrm{GH}$ have selective induction of hepatic GHBP mRNA abundance with a parallel increase in serum GHBP concentrations (unpublished observations). The differences in the developmental patterns of the GHBP and GHR mRNA in kidney and lung may also indicate differential regulation of the two transcripts in a more physiologic model. Although their functional interplay is not understood, the GHBP may compete with the GHR for GH binding $(5,6)$. The GHBP, therefore, might serve as a storage protein that smooths out the pulsatile exposure of cells to $\mathrm{GH}$ and thereby regulates the availability of $\mathrm{GH}$ to the membrane-bound receptor (6). Clearance of GH from the circulation takes place largely in the kidney by glomerular filtration, followed by resorption in the proximal tubule and degradation (26). It is possible that the early postnatal increase in GHBP mRNA in kidney might provide a renally derived GHBP that regulates these processes.

The findings of this study are concordant with published data on the regulation of IGF-I mRNA transcripts, IGF-I peptide, and the known functions of $\mathrm{GH}$ in different tissues, suggesting that GHR mRNA abundance may be a sensitive indicator of tissue responsiveness to $\mathrm{GH}$. Our observation that the GHR and GHBP mRNA are differentially regulated in some tissues supports the emerging evidence that the two proteins have different functions. The study of GHR and GHBP mRNA abundance may therefore contribute to our understanding of the function 
of $\mathrm{GH}$, and the relationship between the GHR and the GHBP, in different physiologic and pathophysiologic models.

Acknowledgments. The authors thank Keith E. Muller, Ph.D., and Douglas J. Taylor, B.S., for their help with the statistical assessment of the data and Steven E. Selub, M.D., and P. Kay Lund, Ph.D., from the Departments of Medicine and Physiology for their assistance and valuable advice.

\section{REFERENCES}

1. Roupas P, Herington AC 1989 Cellular mechanisms in the processing of growth hormone and its receptor. Mol Cell Endocrinol 61:1-12

2. Mathews LS, Enberg B, Norstedt G 1989 Regulation of rat growth hormone receptor gene expression. J Biol Chem 264:9905-9910

3. Emtner M, Mathews LS, Norstedt G 1990 Growth hormone (GH) stimulates protein synthesis in cells transfected with $\mathrm{GH}$ receptor complementary DNA. Mol Endocrinol 4:2014-2020

4. Baumbach WR, Horner DL, Logan JS 1989 The growth hormone-binding protein in rat serum is an alternatively spliced form of the rat growth hormone receptor. Genes Dev 3:1199-1205

5. Lim L, Spencer SA, McKay P, Waters MJ 1990 Regulation of growth hormone $(\mathrm{GH})$ bioactivity by a recombinant human GH-binding protein. Endocrinology 127:1287-1291

6. Mannor DA, Winer LM, Shaw MA, Baumann G 1991 Plasma growth hormone (GH)-binding proteins: effect on $\mathrm{GH}$ binding to receptors and $\mathrm{GH}$ action. J Clin Endocrinol Metab 73:30-34

7. Posner BI, Kelly PA, Shiu RPC, Freisen HG 1974 Studies of insulin, growth hormone and prolactin binding: tissue distribution, species variation and characterization. Endocrinology 95:521-531

8. Bjorn B, Billig H, Rymo L, Isaksson OGP 1990 Expression of the growth hormone-binding protein messenger RNA in the liver and extrahepatic tissues in the rat: co-expression with the growth hormone receptor. Mol Cell Endocrinol 73:R1-R6

9. Chirgwin JM, Pryzybyla AE, MacDonald RJ, Rutter WJ 1979 Isolation of biologically active ribonucleic acid from sources enriched in ribonucleases. Biochemistry 18:5294-5299

10. Aviv H, Leder P 1972 Purification of biologically active globin messenger RNA by chromatography on oligo thymidilic acid cellulose. Proc Natl Acad Sci USA 69:1408-1412

11. Thomas PS 1980 Hybridization of denatured RNA and small DNA fragments transferred to nitrocellulose. Proc Natl Acad Sci USA 77:5201-5205

12. Southern EM 1975 Detection of specific sequences among DNA fragments separated by gel electrophoresis. J Mol Biol 98:503-517

13. Retsch-Bogart GZ, Stiles AD, Moats-Staats BM, Van Scott MR, Boucher RC,
D'Ercole AJ 1990 Canine tracheal epithelial cells express the type 1 insulinlike growth factor receptor and proliferate in response to insulin-like growth factor I. Am J Respir Cell Mol Biol 3:227-234

14. Maxam AM, Gilbert W 1980 Sequencing end-labelled DNA with base-specific chemical cleavages. Methods Enzymol 65:499-506

15. Feinberg AP, Vogelstein B 1984 A technique for radiolabeling DNA restriction endonuclease fragments to high specific activity. Anal Biochem 137:266267

16. Lund PK, Moats-Staats BM, Hynes MA, Simmons JG, Jansen M, D'Ercole AJ, Van Wyk JJ 1986 Somatomedin-C/insulin-like growth factor-II mRNAs in rat fetal and adult tissues. J Biol Chem 261:14539-14544

17. Maes M, De Hertogh R, Watrin-Granger P, Ketelslegers JM 1983 Ontogeny of liver somatotropic and lactogenic binding sites in male and female rats. Endocrinology 113:1325-1332

18. D'Ercole AJ, Stiles AD, Underwood LE 1984 Tissue concentrations of somatomedin C: further evidence for multiple sites of synthesis and paracrine or autocrine mechanisms of action. Proc Natl Acad Sci USA 81:935-939

19. Garcia-Aragon J, Lobie PE, Gobius KS, Waters MJ 1990 Prenatal expression of the growth hormone receptor/binding protein in the rat: a role for growth hormone in embryonic and foetal development? Endocr Soc Aust Proc 33:60(abstr)

20. Ymer SI, Stevenson JL, Herington AC 1989 Differences in the developmental patterns of somatotropic and lactogenic receptors in rabbit liver cytosol. Endocrinology 125:516-523

21. Adamo M, Lowe WL, LeRoith D, Roberts CT 1989 Insulin-like growth factor I messenger ribonucleic acids with alternative $5^{\prime}$-untranslated regions are differentially expressed during development of the rat. Endocrinology $124: 2737-2744$

22. Liu L, Greenberg S, Russell SM, Nicoll CS 1989 Effects of insulin-like growth factors I and II on growth and differentiation of transplanted rat embryos and fetal tissues. Endocrinology 124:3077-3082

23. Davenport ML, D'Ercole AJ, Azizkhan JC, Lund PK 1988 Somatomedin-C/ insulin-like growth factor I (SmC/IGF-I) and insulin-like growth factor II (IGF-II) mR NAs during lung development in the rat. Exp Lung Res 14:607618

24. Glasscock GF, Gelber SE, Lamson G, McGee-Tekula R, Rosenfeld RG 1990 Pituitary control of growth in the neonatal rat: effects of neonatal hypophysectomy on somatic and organ growth, serum insulin-like growth factors (IGF)-I and -II levels, and expression of IGF binding proteins. Endocrinology 127:1792-1803

25. Russell WE 1985 Growth hormone, somatomedins, and the liver. Semin Liver Dis 5:46-58

26. Hammerman MR 1989 The growth hormone-insulin-like growth factor axis in kidney. Am J Physiol 257:F503-F514

27. Castillo RO, Glasscock GF, Noren KM, Reisenauer AM 1991 Pituitary regulation of postnatal small intestinal ontogeny in the rat: differential regulation of digestive hydrolase maturation by thyroxine and growth hormone. Endocrinology 129:1417-1423 